\title{
The roles of glial cell line-derived neurotrophic factor, brain-derived neurotrophic factor and nerve growth factor during the final stage of folliculogenesis: a focus on oocyte maturation
}

\author{
Katja Linher-Melville and Julang $\mathrm{Li}^{1}$ \\ Department of Pathology and Molecular Medicine, McMaster University, Hamilton, Ontario, L8S4L8 Canada and \\ ${ }^{1}$ Department of Animal and Poultry Science, University of Guelph, Guelph, Ontario, NIG2W1 Canada
}

Correspondence should be addressed to J Li; Email: jli@uoguelph.ca

\begin{abstract}
Neurotrophic factors were first identified to promote the growth, survival or differentiation of neurons and have also been associated with the early stages of ovarian folliculogenesis. More recently, their effects on the final stage of follicular development, including oocyte maturation and early embryonic development, have been reported. Glial cell line-derived neurotrophic factor (GDNF), brain-derived neurotrophic factor (BDNF) and nerve growth factor (NGF), which are expressed in numerous peripheral tissues outside of the CNS, most notably the ovary, are now known to stimulate oocyte maturation in various species, also enhancing developmental competence. The mechanisms that underlie their actions in antral follicles, as well as the targets ultimately controlled by these factors, are beginning to emerge. GDNF, BDNF and NGF, alone or in combination, could be added to the media currently utilized for in vitro oocyte maturation, thereby potentially increasing the production and/or quality of early embryos.
\end{abstract}

Reproduction (2013) 145 R43-R54

\section{Introduction}

Considerable insights have been gained into understanding the factors and mechanisms that regulate the assembly, growth and development of ovarian follicles, from the initial differentiation of primordial follicles to the proliferation of granulosa cells and the ability of later stage follicles to respond to FSH, which are the topics reviewed elsewhere (Dierich et al. 1998, Kezele et al. 2002, Skinner 2005, Craig et al. 2007). Over the last several decades, neurotrophic factors, originally identified as affecting cells of the CNS, have also been recognized to play important roles in peripheral tissues, including the highly innervated ovary. Ovarian nerve fibres not only connect with blood vessels but also associate with follicles (Malamed et al. 1992), and it has been shown that ectopic transplantation of the ovary results in rapid in-growth of nerve fibres (Lara et al. 1991). Local ovarian production of neuronal growthpromoting factors, coupled with the initial insensitivity of developing embryonic ovaries to gonadotrophins, suggested that early events during folliculogenesis could, at least in part, be under neurotrophic control (Lara et al. 1991, Malamed et al. 1992). This notion was supported by the finding that neurotrophins and their receptors are expressed in the ovary before the acquisition of gonadotrophin responsiveness (Dissen et al. 1995, 2009). It is now evident that neurotrophins, together with other growth factors and hormones, exert a substantial influence on both somatic cells and germ cells in the embryo during the early stages of folliculogenesis (Dissen et al. 2009), with developing oocytes and granulosa cells maintaining a bidirectional relationship similar to the communication existing between neurons and glial cells (Davies \& Wright 1995).

The effects of neurotrophins on developing ovarian follicles have been investigated in the context of follicular survival, assembly and growth (Paredes et al. 2004, Dole et al. 2008, Dissen et al. 2009, Kerr et al. 2009, Dorfman et al. 2011) and have been reviewed elsewhere (Ojeda et al. 2000, Dissen et al. 2002, 2009). However, studies investigating their role in antral follicles during the final stage of folliculogenesis, marked by oocyte maturation and the resumption of meiosis, which is concomitant with extrusion of the first polar body, as well as developmental competence of the early embryo, have not been reviewed in detail. The acquisition of developmental competence or the ability to support preimplantation embryo development following fertilization is linked to both cytoplasmic and nuclear maturation of the oocyte and requires that it be 
able to adequately transmit signals derived from endocrine, autocrine and paracrine stimuli within the cumulus-oocyte complex (COC). The maintenance of this coordinated crosstalk and the complex signalling network within antral follicles are essential to drive two closely linked processes, oocyte developmental competence and cumulus cell expansion. After the preovulatory LH surge, cumulus cells expand, which corresponds with the resumption of meiosis and also serves as an indirect marker of COC maturation. It has become evident that neurotrophins are present within oocytes and somatic cells comprising antral follicles, as well as in follicular fluid. As recent findings suggest that neurotrophins play a key role during oocyte maturation, the expression and effects of glial cell line-derived neurotrophic factor (GDNF), brain-derived neurotrophic factor (BDNF) and nerve growth factor (NGF) and their respective receptors will be discussed. In addition, emerging evidence regarding the possible mechanisms underlying neurotrophin-mediated oocyte maturation and regulation of ovarian expression will be presented, as well as the potential clinical significance of these neurotrophic factors.

\section{Expression of neurotrophic factors in the postnatal ovary}

\section{Glial cell line-derived neurotrophic factor}

GDNF, a distant member of the TGFB superfamily, is related to a subset of neurotrophic ligands that also includes neurturin, artemin and persephin (Takahashi 2001). First identified as promoting the survival and differentiation of several classes of peripheral and central neurons (Lin et al. 1993, Tomac et al. 1995), GDNF is now known to play diverse roles outside of the CNS. Interestingly, a comparative analysis of its mRNA levels by in situ hybridization in a panel of murine tissues revealed Gdnf to be most prominently expressed in the ovary, where it was found to localize to the urogenital system throughout various stages of embryonic development and in the adult ovary (Golden et al. 1999), primarily within the granular layer of developing follicles (Widenfalk et al. 2000). Murine Gdnf mRNA levels have been reported to be low in maturing follicles, increasing significantly in those closest to maturity (Golden et al. 1999). In addition to its transcript, murine GDNF protein localizes to oocytes as well as granulosa and stromal cells (Aravindakshan et al. 2006). A DNA microarray analysis conducted by Kawamura et al. (2008) also identified Gdnf as an important ovarian transcript in the mouse, with follow-up experiments revealing that this factor is expressed by ovarian somatic cells, including cumulus, granulosa and theca cells (Kawamura et al. 2008). In rats, Gdnf mRNA is present in the neonatal and adult ovary (Choi-Lundberg \& Bohn 1995, Trupp et al. 1995), and in the ovaries of newborns, GDNF protein localizes to the cytoplasm of oocytes in follicles representing all developmental stages, and to cumulus, granulosa and theca cells within antral follicles (Dole et al. 2008).

GDNF elicits its responses through a receptor complex composed of a glycosylphosphatidylinositol-linked ligand-binding subunit, the GDNF family co-receptor alpha 1 (GFRA1), and its signalling component, the rearranged during transfection (RET) tyrosine kinase receptor (Trupp et al. 1995, Jing et al. 1996, Baloh et al. 2000). RET does not bind directly to GDNF (Treanor et al. 1996), requiring the recruitment of GFRA1 for its transactivation, thereby initiating intracellular signalling (Sariola \& Saarma 2003). An ovarian Ret mRNA signal has been detected in mice (Widenfalk et al. 2000), and Gfra1 and Ret are co-expressed in the developing urogenital system (Golden et al. 1999). In rats, GFRA1 protein was shown to localize to oocytes within primordial and primary follicles, while in antral follicles, the receptor was present in granulosa and theca cells (Dole et al. 2008). Consistent with studies conducted in rodents, work in our laboratory revealed that in the pig, GDNF and both its receptors are expressed in COCs at the mRNA and protein levels during the final stages of folliculogenesis and that GDNF is present in porcine follicular fluid derived from COCs isolated from both small, less mature and larger, more mature antral follicles (Linher et al. 2007). Recently, GDNF and its receptors were detected at the mRNA and protein levels in oocytes and granulosa cells from human fetuses collected from terminated pregnancies at 21-35 weeks of gestation and in girls and women 5-39 years of age who underwent ovarian laparoscopies (Farhi et al. 2010). Furthermore, single-cell screening for growth factors that could potentially enhance the maturation of cumulus-free, denuded oocytes isolated from patients receiving ICSI treatment revealed that GDNF mRNA levels were significantly higher in cumulus cells than in oocytes, while GFRA1 appeared to be exclusively expressed in oocytes (McElroy et al. 2010). Expanding on its presence in the human ovary during the later stages of folliculogenesis, GDNF protein localized to unstimulated human granulosa cells obtained from women undergoing in vitro maturation (IVM) procedures (Zhao et al. 2011). Cumulatively, paired with data obtained in other mammals, these expression patterns, which are also summarized in Table 1, suggest that GDNF influences the oocyte and cumulus cells in both a paracrine and a autocrine manner within the adult ovary.

\section{Brain-derived neurotrophic factor}

The neurotrophin BDNF is a member of a family of neurotrophic factors that includes NGF as well as neurotrophin 3 (NTF3), NTF4/5 and NTF6 (Bibel \& Barde 2000, Lu et al. 2005). Each of these ligands is required for the survival and differentiation of central and 
Table 1 Expression profile and function of GDNF in the ovary.

\begin{tabular}{|c|c|c|c|c|c|}
\hline Expression & Species & Reference & Function & Species & Reference \\
\hline $\begin{array}{l}\text { Adult ovary, granular layer of } \\
\text { developing follicles }\end{array}$ & Mouse & $\begin{array}{l}\text { Golden et al. (1999) } \\
\text { and Widenfalk } \\
\text { et al. (2000) }\end{array}$ & & & \\
\hline Oocytes, ovarian stromal cells & Mouse & $\begin{array}{l}\text { Aravindakshan et al. } \\
\quad(2006)\end{array}$ & & & \\
\hline $\begin{array}{l}\text { Ovarian follicles, cumulus, granu- } \\
\text { losa and theca cells; oviducts and } \\
\text { uteri of pregnant females }\end{array}$ & Mouse & Kawamura et al. (2008) & $\begin{array}{l}\uparrow \text { Cyclin D1 levels } \\
\uparrow \text { Extrusion of } 1 \text { st polar body } \\
\uparrow \text { Development of two-cell } \\
\text { stage embryos into } \\
\text { blastocysts }\end{array}$ & Mouse & Kawamura et al. (2008) \\
\hline Neonatal and adult ovary & Rat & $\begin{array}{l}\text { Choi-Lundberg \& Bohn } \\
\text { (1995) and Trupp } \\
\text { et al. (1995) }\end{array}$ & & & \\
\hline $\begin{array}{l}\text { Primarily in oocytes, to a lesser } \\
\text { extent in cumulus, granulosa and } \\
\text { theca cells }\end{array}$ & Rat & Dole et al. (2008) & & & \\
\hline $\begin{array}{l}\text { COCs (oocytes, cumulus cells), } \\
\text { granulosa and theca cells, } \\
\text { follicular fluid }\end{array}$ & Pig & Linher et al. (2007) & $\begin{array}{l}\uparrow \text { Cyclin D1 levels } \\
\uparrow \text { Extrusion of } 1 \text { st polar body } \\
\uparrow \text { Developmental compe- } \\
\text { tence of oocytes from less } \\
\text { mature follicles to reach } \\
\text { the blastocyst stage }\end{array}$ & Pig & Linher et al. (2007) \\
\hline $\begin{array}{l}\text { Oocytes and granulosa cells from } \\
\text { fetuses, girls and women }\end{array}$ & Human & Farhi et al. (2010) & & & \\
\hline Oocytes, cumulus cells & Human & McElroy et al. (2010) & $\begin{array}{l}\text { In combination with a } \\
\text { cocktail of other factors: } \\
\uparrow \text { Oocyte nuclear maturation } \\
\uparrow \text { Formation of parthenoge- } \\
\text { netic blastocysts }\end{array}$ & Human & McElroy et al. (2010) \\
\hline Granulosa cells & Human & Zhao et al. (2011) & $\begin{array}{l}\uparrow \text { Total number of oocytes } \\
\text { reaching MII }\end{array}$ & Human & Zhao et al. (2011) \\
\hline Follicular fluid & Human & Sadeu et al. (2012) & & & \\
\hline
\end{tabular}

peripheral neurons and signals through distinct high-affinity transmembrane receptor tyrosine kinases, as well as through a common, more widely expressed, low-affinity neurotrophin receptor (NGFR), also known as p75 (Raffioni et al. 1993, Snider 1994, Davies 2000). Transcripts for these neurotrophins and their receptors have been detected in the rat ovary before the neonatal phase of development (Dissen et al. 1995), indicating a role during ovarian differentiation and the initiation of folliculogenesis in the embryo. BDNF binds to and activates either neurotrophic tyrosine kinase receptor 2 (NTRK2), also known as TRKB, or p75 (Klein et al. 1991), which can amplify (Hantzopoulos et al. 1994) or inhibit (Kohn et al. 1999) the actions mediated through the different NTRK receptors. A role for BDNF in the ovary was established in vivo using knockout mouse models of all Ntrk2 receptor isoforms or their ligands $B d n f / N t f 4 / 5$ (Paredes et al. 2004), revealing defects in murine early follicular development by impeding the growth of follicles beyond the primary stage. Ntrk2 mRNA has been detected in oocytes and granulosa cells in a manner dependent on the stage of ovarian development (Dissen et al. 1995, Anderson et al. 2002, Paredes et al. 2004). In the neonatal mouse ovary, BDNF and NTRK2 are initially present in oocytes, with their expression switching to granulosa cells following the assembly of primordial follicles and further development into primary follicles
(Paredes et al. 2004). In the neonatal rat ovary, both Bdnf and its receptors are expressed at the mRNA level before the onset of folliculogenesis, before the formation of primordial follicles (Dissen et al. 1995), which follows a similar temporal pattern as described in the human fetal ovary (Anderson et al. 2002). Seifer et al. (2002a, 2002b) demonstrated by immunocytochemistry that NTRK2 is expressed in a majority of murine oocytes (Seifer et al. 2002a), which was corroborated by a separate study demonstrating its exclusive expression in murine oocytes (Kawamura et al. 2005). Bovine cumulus cells and oocytes were reported to express BDNF and NGFR at both the mRNA and the protein levels (Martins da Silva et al. 2005). However, contrary to the results observed in rodents, bovine NTRK2 mRNA was detected only in cumulus cells (Martins da Silva et al. 2005). Porcine COCs express mRNA for BDNF and its receptors in both follicular somatic cells and oocytes, while NTRK2 was not detected in oocytes (Lee et al. 2007). In women undergoing IVF, BDNF was present in follicular fluid, with the source of BDNF identified to be derived exclusively from cumulus cells, as neither cultured oocytes stripped of cumulus cells, mural granulosa cells or embryos released any appreciable levels of BDNF into the culture medium (Seifer et al. 2002a). In addition, BDNF is also present in follicular fluid from normally cycling women (Seifer et al. 2003). In a recent 
study, it was shown that BDNF protein localizes to unstimulated human granulosa cells isolated from patients undergoing IVM (Zhao et al. 2011). Similar to GDNF, these ovarian patterns of expression support that BDNF mediates aspects of both the early and the later stages of folliculogenesis. Although there appear to be considerable species differences with regard to the localization of its expression within a follicle (Table 2), BDNF most likely influences the maturing oocyte in a paracrine manner.

\section{Nerve growth factor}

NGF signals through NTRK1, also known as TRKA (Raffioni et al. 1993), as well as through NGFR. One of the first studies demonstrating that NGF is locally produced in the immature rat ovary showed the presence of an mRNA similar to the mature Ngf mRNA detected in the murine submaxillary gland, an established source of its production (Lara et al. 1990). Furthermore, NGF protein was also confirmed to be present in neonatal rat ovaries (Lara et al. 1990). A temporal analysis of Ngf and Ntrk1 mRNA levels revealed that in the rat ovary, both the ligand and the receptor are present during fetal development and decrease in the neonate, remaining low until the onset of puberty, at which time the expression of both rises (Dissen et al. 1995). In particular, Ntrk1 mRNA levels increased concomitantly with the LH surge, and it has therefore been suggested that NGF may play a role in controlling ovulation (Dissen et al. 1996). NTRK1 also localizes to theca cells in large antral follicles in the rat (Dissen et al. 1996), supporting this notion. In sheep, NGF was present in the follicular fluid, and NTRK1 localized exclusively to cumulus cells, as oocytes were found to be negative for this receptor in ovine follicles (Barboni et al. 2002). NGF, NTRK1 and NGR were expressed in porcine oocytes, granulosa cells and theca cells throughout an oestrous cycle, with NGF staining more predominantly in large, antral follicles than in follicles of smaller diameter (Jana et al. 2011), suggesting that it plays an important role during oocyte maturation. During the oestrous cycle of the golden hamster, NGF, NTRK1 and NGFR were reported to localize to oocytes, granulosa cells and theca cells of follicles representing various stages of folliculogenesis and their presence was also detected in interstitial and luteal cells (Shi et al. 2004). In humans, NGF was present in normally cycling women (Seifer et al. 2003), and it has also been quantified in the follicular fluid of women undergoing IVF and ovulation induction for fertility

Table 2 Expression profile and function of BDNF in the ovary.

\begin{tabular}{|c|c|c|c|c|c|}
\hline Expression & Species & Reference & Function & Species & Reference \\
\hline $\begin{array}{l}\text { Granulosa cells of primordial } \\
\text { and primary follicles }\end{array}$ & Mouse & Paredes et al. (2004) & & & \\
\hline \multirow[t]{3}{*}{$\begin{array}{l}\text { Secreted by cumulus and } \\
\text { granulosa cells }\end{array}$} & Mouse & Kawamura et al. (2005) & $\begin{array}{l}\uparrow \text { Extrusion of 1st polar } \\
\text { body } \\
\uparrow \text { In vitro development of } \\
\text { zygotes into preimplan- } \\
\text { tation embryos }\end{array}$ & Mouse & Kawamura et al. (2005) \\
\hline & & & & Mouse & $\begin{array}{l}\text { Zhang et al. (2010a, } \\
\text { 2010b) }\end{array}$ \\
\hline & & & $\begin{array}{l}\text { Improved meiotic spindle } \\
\text { configuration and loca- } \\
\text { lization/distribution of } \\
\text { cortical granules at MI }\end{array}$ & & \\
\hline $\begin{array}{l}\text { Neonatal rat ovary before pri- } \\
\text { mordial follicle formation }\end{array}$ & Rat & Dissen et al. (1995) & & & \\
\hline \multirow[t]{2}{*}{ Oocytes and cumulus cells } & Cow & $\begin{array}{l}\text { Martins da Silva et al. } \\
\text { (2005) }\end{array}$ & $\begin{array}{l}\uparrow \text { Blastocyst rate of } \\
\text { parthenogenetically } \\
\text { activated embryos }\end{array}$ & Cow & $\begin{array}{l}\text { Martins da Silva et al. } \\
\text { (2005) }\end{array}$ \\
\hline & & & $\begin{array}{l}\uparrow \begin{array}{l}\text { Percentage of Mll } \\
\text { oocytes }\end{array} \\
\text { t }\end{array}$ & Cow & Hong et al. (2009) \\
\hline $\begin{array}{l}\text { Oocytes and follicular somatic } \\
\text { cells }\end{array}$ & Pig & Lee et al. (2007) & $\begin{array}{l}\uparrow \text { Extrusion of } 1 \text { st polar } \\
\text { body } \\
\uparrow \text { Developmental compe- } \\
\text { tence to reach the blas- } \\
\text { tocyst stage }\end{array}$ & Pig & Lee et al. (2007) \\
\hline Follicular fluid & Human & $\begin{array}{l}\text { Seifer et al. (2002a, } \\
2002 b, 2003) \text { and } \\
\text { Sadeu et al. (2012) }\end{array}$ & $\begin{array}{l}\uparrow \text { Extrusion of } 1 \text { st polar } \\
\text { body }\end{array}$ & Mouse & $\begin{array}{l}\text { Seifer et al. (2002a, } \\
\text { 2002b) }\end{array}$ \\
\hline Granulosa cells & Human & Zhao et al. (2011) & $\begin{array}{l}\uparrow \text { Total number of MII } \\
\text { oocytes }\end{array}$ & Human & Zhao et al. (2011) \\
\hline Oocytes and cumulus cells & Human & Anderson et al. (2010) & $\begin{array}{l}\text { Blocking antibodies } \\
\text { against BDNF } \uparrow \text { num- } \\
\text { ber of MII oocytes } \\
\uparrow \text { Failure to cleave when } \\
\text { included in IVM media }\end{array}$ & Human & Anderson et al. (2010) \\
\hline
\end{tabular}


treatment (Seifer et al. 2002a, Buyuk \& Seifer 2008, Sadeu et al. 2012). Its mRNA and protein are expressed in human granulosa cells and oocytes isolated from fetal ovaries collected at 19-33 weeks of gestation and in ovarian samples derived from girls and women aged 13-39 years, while NTRK1 was primarily detected in oocytes (Abir et al. 2005). NGF and NTRK1 were also detected in human preantral and antral follicle-derived granulosa cells and in theca cells of antral follicles (Salas et al. 2006). The cumulative ovarian expression profile of NGF (Table 3) supports both a paracrine and a autocrine influence on oocytes and cumulus cells.

\section{Regulation of ovarian function by neurotrophins}

Although GDNF promotes diverse functions in several different tissues, its potential role in the ovary has, until recently, remained relatively unexplored. It has been suggested that GDNF may contribute to the onset of ovarian tumorigenesis in ageing mutant mice carrying a disruption in the $\mathrm{FSH}$ receptor $(F s h r)$ gene (Aravindakshan et al. 2006). In addition, a role for GDNF in promoting primordial follicle development in 4-day-old rats has been described, demonstrating that ovaries maintained in organ culture and treated with GDNF contain significantly more developing follicles compared with untreated controls (Dole et al. 2008). Regarding its influence on the later stages of follicular development, particularly oocyte maturation, our laboratory has reported that GDNF stimulates oocyte nuclear and cytoplasmic maturation as well as cumulus cell expansion in the pig, also enhancing the developmental competence of porcine oocytes derived from small, less mature antral follicles (Linher et al. 2007).
More specifically, we observed GDNF to promote nuclear maturation of oocytes as measured by first polar body extrusion, signifying meiotic progression to MII, and addition of GDNF to the IVM media also increased oocyte cyclin B1 protein levels (Linher et al. 2007). These effects were mediated by GFRA 1 , as a blocking antibody reversed the functional effects of GDNF. Our work further demonstrated that GDNF preferentially enhances the competence of small follicle-derived antral oocytes to support preimplantation embryo development to the blastocyst stage, increasing the percentage of blastocysts to levels obtained for untreated large, more meiotically competent antral follicle-derived oocytes (Linher et al. 2007). Similar studies on mouse revealed that, following treatment of COCs with GDNF, murine oocytes underwent enhanced extrusion of the first polar body, and cyclin B1 protein levels were also significantly increased (Kawamura et al. 2008). While inclusion of GDNF in the IVM media does not enhance preimplantation development in the mouse, treatment of cultured early murine embryos at the two-cell stage with GDNF specifically enhances the percentage that reaches the expanded and hatched blastocyst stages, as use of a GDNF-neutralizing antibody blocked this effect (Kawamura et al. 2008). Of particular interest, during these early stages of mouse preimplantation embryo development, GDNF was found to be expressed in the oviducts and uteri of pregnant mice, and both its co-receptors were expressed in embryos, demonstrating that this factor not only supports oocyte maturation and blastocyst formation in vitro but it also has a physiologically relevant role to support early embryonic development in vivo (Kawamura et al. 2008).

Table 3 Expression profile and function of NGF in the ovary.

\begin{tabular}{|c|c|c|c|c|c|}
\hline Expression & Species & Reference & Function & Species & Reference \\
\hline \multirow[t]{2}{*}{ Fetal, neonatal and adult ovary } & Rat & $\begin{array}{l}\text { Lara et al. (1990) and } \\
\text { Dissen et al. (1995, } \\
\text { 1996) }\end{array}$ & Possible role during ovulation & Rat & Dissen et al. (1996) \\
\hline & & & $\begin{array}{l}\uparrow \text { Formation of parthenoge- } \\
\text { netic pronuclei } \\
\uparrow \text { Resumption of meiosis }\end{array}$ & Mouse & $\begin{array}{l}\text { Fedorushchenko et al. } \\
\quad(1996,1999)\end{array}$ \\
\hline Follicular fluid & Sheep & Barboni et al. (2002) & $\begin{array}{l}\uparrow \text { Resumption of meiosis } \\
\uparrow \text { Cumulus cell expansion }\end{array}$ & Sheep & Barboni et al. (2002) \\
\hline $\begin{array}{l}\text { Oocytes, granulosa cells and } \\
\text { theca cells }\end{array}$ & Pig & Jana et al. (2011) & & & \\
\hline \multirow{3}{*}{$\begin{array}{l}\text { Oocytes, granulosa cells, theca } \\
\text { cells, interstitial and luteal cells }\end{array}$} & Golden & Shi et al. (2004) & & & \\
\hline & & & $\begin{array}{l}\uparrow \text { Germinal vesicle break- } \\
\text { down }\end{array}$ & Xenopus & Nebreda et al. (1991) \\
\hline & & & $\begin{array}{l}\text { Activation of maturation-pro- } \\
\text { moting factor }\end{array}$ & & \\
\hline Follicular fluid & Human & $\begin{array}{l}\text { Seifer et al. (2002a, } \\
\text { 2002b, 2003), Buyuk } \\
\text { \& Seifer (2008) and } \\
\text { Sadeu et al. (2012) }\end{array}$ & & & \\
\hline $\begin{array}{l}\text { Oocytes, granulosa cells and } \\
\text { theca cells }\end{array}$ & Human & $\begin{array}{l}\text { Abir et al. (2005) and } \\
\text { Salas et al. (2006) }\end{array}$ & & & \\
\hline
\end{tabular}


In further support of our initial findings using a porcine model and studies conducted in rodents, it has recently been shown that in women undergoing IVM, GDNF enhances the total number of human oocytes that reach MII (Zhao et al. 2011). Furthermore, inclusion of GDNF in IVM medium containing a defined mixture of other important ovarian factors (BDNF, insulin-like growth factor 1 , oestradiol, fibroblast growth factor 2 (FGF8), and leptin) resulted in a greater percentage of human oocytes that attained nuclear maturation as well as enhanced parthenogenetic blastocyst formation (McElroy et al. 2010). It is therefore becoming increasingly apparent that GDNF, which is normally present in follicular fluid, has distinct, stage-dependent effects on oocyte maturation beyond its previously recognized roles. These findings support the notion that GDNF acts as an important intra-ovarian regulator during follicular development (Table 1).

BDNF is also able to promote oocyte maturation. Obtaining follicular aspirates from women undergoing IVM, Seifer et al. (2002a) were the first to show that BDNF is secreted by cumulus cells into follicular fluid. Due to the constraints of using human COCs, their study also utilized murine oocytes as a model to evaluate a possible role for BDNF during oocyte maturation, revealing that this neurotrophin significantly enhances the percentage of oocytes extruding a first polar body (Seifer et al. 2002a). Results of a DNA microarray analysis of ovarian transcripts led Kawamura et al. (2005) to identify BDNF as a factor stimulated by the LH surge, also demonstrating that it is secreted by murine granulosa and cumulus cells (Kawamura et al. 2005). Furthermore, with NTRK2 expressed exclusively in oocytes, BDNF acted as a paracrine factor that enhanced the extrusion of the first polar body, also promoting the developmental competence of preimplantation embryos (Kawamura et al. 2005). Both these BDNF-mediated effects were specifically blocked using a NTRK2 receptor inhibitor. In a more detailed study using immunofluorescence and confocal laser microscopy, Zhang et al. (2010a, 2010b) demonstrated that BDNF promotes the maturation of murine IVM oocytes by affecting key morphological characteristics, namely by improving the configuration of meiotic spindles and the localization and distribution of cortical granules at $\mathrm{MI}$ (Zhang et al. 2010a). BDNF also enhanced the rate at which parthenogenetically activated bovine embryos derived from large, more mature preovulatory oocytes reached the blastocyst stage (Martins da Silva et al. 2005). Unlike what has been reported in rodents, in the cow, BDNF did not appear to affect nuclear maturation (Martins da Silva et al. 2005). However, in a recent study, it was shown that BDNF does significantly increase the percentage of bovine MII oocytes, while no statistically significant changes were recorded for its effect on development to the blastocyst stage (Hong et al. 2009). As a potential candidate for improving in vitro culture and embryo production of porcine oocytes, inclusion of BDNF in the IVM medium significantly increased first polar body extrusion, as well as enhancing oocyte developmental competence to reach the blastocyst stage following IVF and somatic cell nuclear transfer (Lee et al. 2007). In COCs derived from women undergoing laparoscopy who were then subjected to IVM, BDNF did not affect MII yields (Anderson et al. 2010). Indeed, paradoxically, inclusion of two different blocking antibodies against BDNF in the IVM medium improved the percentage of MII oocytes. In activated human oocytes, treatment with these same blocking antibodies resulted in the highest rate of abnormal cleavage, while failure to cleave was highest when BDNF was included in the culture media (Anderson et al. 2010). However, BDNF has also been reported to enhance the total number of human immature, cultured oocytes that reach MII (Zhao et al. 2011). From these combined findings, it is clear that BDNF signalling does play a role during the final stages of follicular development by affecting oocyte maturation but that its effects may be species dependent, or dependent on the particular paradigm applied for IVM (Table 2).

NGF was first shown to play a role during Xenopus laevis oocyte maturation, as the presence of its microinjected receptor RNA potentiated the effects of progesterone (Sehgal et al. 1988). Furthermore, Xenopus oocytes injected with NTRK1 RNA and subsequently treated with NGF underwent breakdown of the germinal vesicle and activation of maturation-promoting factor, two markers of meiotic maturation (Nebreda et al. 1991). This finding was also observed in murine oocytes that were injected with NGF, which subsequently displayed an increased ability to form parthenogenetic pronuclei in both oocytes within COCs and denuded oocytes (Fedorushchenko et al. 1999). The same group also showed that addition of NGF to IVM media induced the resumption of meiosis in murine oocytes cultured without cumulus cells following gonadotrophin stimulation (Fedorushchenko et al. 1996). However, the developmental competence of one-cell stage bovine embryos produced by IVM or IVF was not enhanced after culture in the presence of NGF (Flood et al. 1993). During ovine IVM, NGF significantly enhanced cumulus cell expansion, also inducing the resumption of meiosis in oocytes to levels comparable to those achieved with gonadotrophin stimulation (Barboni et al. 2002). The finding that NGF levels increased in follicular fluid from sheep following the LH surge (Barboni et al. 2002) further supported that this neurotrophin plays a role during final oocyte maturation. However, in the pig, NGF failed to enhance the percentage of oocytes that reached the MII stage following IVM and did not affect the developmental competence of early embryos (Papp et al. 2005), which could, similar to the cow, be due to species differences. A summary of the effects of NGF on oocyte maturation is outlined in Table 3. 


\section{Putative mechanisms underlying neurotrophin expression and action in the postnatal ovary}

One means by which GDNF may influence oocyte maturation is by affecting the expression of the germ cell-specific regulator deleted in azoospermia-like (DAZL). This relationship was investigated in our laboratory using porcine oocytes as a model, revealing that maximum levels of DAZL mRNA and DAZL protein are associated with MII oocytes (Liu et al. 2009). This finding suggests that DAZL, which is known to regulate translation of the synaptonemal complex component SYCP3, an essential player during meiosis (Reynolds et al. 2007), may also influence the meiotic maturation of oocytes. It has previously been shown that the presence of human DAZL mRNA is positively associated with blastocyst quality (Cauffman et al. 2005), and DAZL may therefore be required for mature oocytes to acquire full developmental competence to sustain preimplantation embryo development. Interestingly, inclusion of GDNF in the IVM media significantly increased $D A Z L$ mRNA and DAZL protein levels during porcine oocyte maturation, while exclusion of FSH or epidermal growth factor (EGF) from the IVM media decreased its mRNA level (Liu et al. 2009). These findings suggest that GDNF, FSH and EGF signalling cascades are likely converging to up-regulate DAZL expression, which in turn affects the expression of other key proteins, thereby enhancing oocyte maturation (Fig. 1).

A microarray analysis conducted by Dole et al. (2008) in the neonatal rat ovary examined changes in gene expression in response to GDNF. GDNF altered the expression of 28 genes, most notably those encoding known growth factors and secreted cytokines. Among these, the transcript for growth differentiation factor 9 (Gdf9), an oocyte-secreted factor essential for normal follicular development during the primary follicle stage

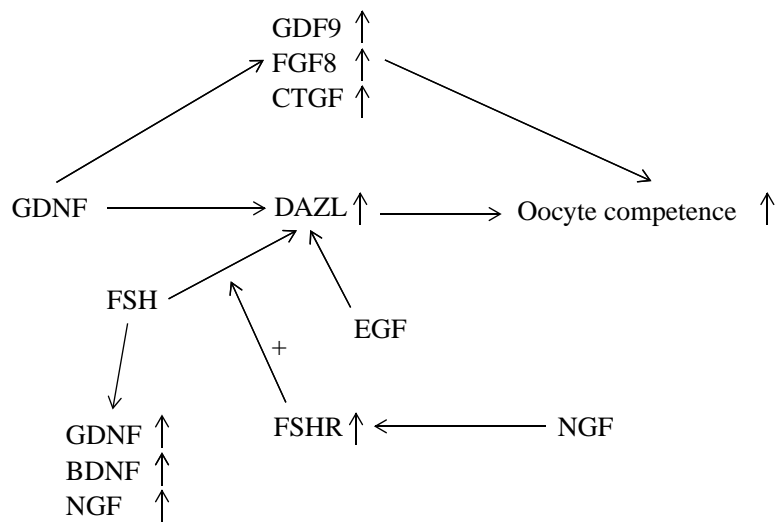

Figure 1 Putative mechanisms of neurotrophin action in the ovary. In conjunction with FSH and EGF, GDNF enhances DAZL expression, an oocyte marker associated with oocyte developmental competence and blastocyst quality. NGF enhances follicular gonadotrophin responsiveness by increasing FSHR expression. In addition, FSH also increases the expression of GDNF, BDNF and NGF in antral follicles. sustained until ovulation (Dong et al. 1996, Elvin et al. 1999), was up-regulated by GDNF (Dole et al. 2008). Other notable transcripts that increased in GDNF-treated ovaries that may play a role during the final stages of folliculogenesis and oocyte maturation included Fgf8 and connective tissue growth factor (Ctgf; Dole et al. 2008). In the ovaries of adult rodents, the detection of Fgf8 mRNA was restricted to oocytes derived from antral follicles, while no signal was detected in fetal ovaries or in primordial follicles of the adult ovary. This expression profile suggests that FGF8 plays a paracrine role, signalling between the oocyte and follicular somatic cells during the final stages of follicular maturation (Valve et al. 1997). However, it has been reported that FGF8 is expressed in oocytes, granulosa cells and theca cells within bovine antral follicles (Buratini et al. 2005), suggesting an autocrine/paracrine mode of signalling. CTGF is a matrix-associated heparin binding protein that is regulated by gonadotrophins and is expressed in antral follicles and corpus lutea in the rat (Harlow et al. 2007). Its function in the ovary remains to be determined.

It has been established that NGF increases Fshr mRNA levels in the neonatal rat ovary in a CAMP-independent manner, as Fshr expression was significantly lower in NGF-null mutant mice (Romero et al. 2002). These findings suggest that by modulating FSHR levels, NGF mediates differentiation during the embryonic stages of folliculogenesis, facilitating the mechanism by which preantral follicles become gonadotrophin dependent. It has since been shown that NGF also plays a role in the adult ovary, affecting the function of human granulosa cells by increasing oestradiol secretion while reducing progesterone levels (Salas et al. 2006). Treatment of human granulosa cells with NGF increased FSHR mRNA levels, which was abrogated by the Trk tyrosine kinase blocker K252a. Also, NGF pretreatment of human granulosa cells resulted in higher secretion of oestradiol after exposure to FSH compared with cells that were not pretreated (Salas et al. 2006). These combined results demonstrate that one of the mechanisms by which NGF may influence antral follicles is by preventing early luteinization through inhibition of progesterone secretion, mediated by increased oestradiol production and increased expression of FSHRs, thereby making the maturing COCs more responsive to gonadotrophins. Based on these findings, a proposed model of putative mechanisms of neurotrophin action in the ovary is presented in Fig. 1.

\section{Potential mechanisms regulating the ovarian expression of neurotrophins and their respective receptors}

Several studies offer insights into how ovarian neurotrophin expression is regulated. In the brain, oestrogen affects $B D N F$ mRNA levels during neural development 
and ageing (Toran-Allerand 1996a, 1996b). Whether local oestradiol produced by granulosa cells within the ovary also alters extraneuronal neurotrophin expression remains to be determined. However, it has been shown that circulating levels of oestradiol are positively associated with BDNF concentrations in women undergoing fertility treatment (Monteleone et al. 2007), and plasma BDNF levels fluctuate during a menstrual cycle (Cubeddu et al. 2011), declining in post-menopausal women (Lommatzsch et al. 2005, Begliuomini et al. 2007, Pluchino et al. 2009), but can be increased through hormone replacement (Begliuomini et al. 2007). Steroid hormones also influence NGF. The effects of oestrogen and progesterone on uterine NGF and NTRK1 expression have been evaluated in ovariectomized adult female golden hamsters, revealing that treatment with either hormone stimulates NGF and NTRK1 levels, although no additive effects were observed (Shi et al. 2006).

One possible pathway activated by BDNF through NTRK2-mediated signalling in murine cumulus cells and oocytes during IVM is via protein kinase B (PKB), as it was found that the pan-specific Trk inhibitor, K252a, together with BDNF, inhibited PKB phosphorylation. While BDNF also increased phosphorylation of MAPK in oocytes, K252a coupled with BDNF did not affect MAPK activation (Zhang et al. 2010b). During human oocyte maturation, CAMP has been identified as a signalling molecule that dose dependently increases the production and secretion of BDNF from cumulus cells (Seifer et al. 2002a). This result was confirmed using forskolin, which activates intracellular adenylate cyclase and in turn leads to increases in intracellular cAMP levels. Inclusion of forskolin in cumulus cell cultures resulted in a significant increase in BDNF production (Seifer et al. 2002a). Based on these findings, it was hypothesized that binding of gonadotrophins to cumulus cells results in activation of CAMP, thereby increasing the production and secretion of BDNF, which in turn elicits a paracrine effect by binding to NTRK2 present on oocytes (Seifer et al. 2002a).

The notion that gonadotrophins influence the expression of neurotrophins is also supported by the finding that NGF follicular fluid concentrations increased dramatically in ovine large, antral follicles in response to gonadotrophin stimulation (Barboni et al. 2002) and in golden hamsters, the LH surge induced NGF, NTRK1 and NGFR protein expression in ovarian interstitial cells (Weng et al. 2009). Furthermore, BDNF secretion by cumulus and granulosa cells was increased in women undergoing IVF in response to treatment with $\mathrm{LH}$, human chorionic gonadotrophin (hCG) or menopausal urinary gonadotrophin (Feng et al. 2003), and a recent study conducted by Zhao et al. (2011) demonstrated that both GDNF and BDNF mRNA levels were slightly increased following FSH treatment of unstimulated human granulosa cells derived from women undergoing IVM (Zhao et al. 2011). This was similar to the changes in expression reported in mice following the preovulatory LH/hCG surge (Kawamura et al. 2005, 2008). Furthermore, the expression of each transcript was significantly increased in response to treatment with either hCG or a combination of FSH and hCG (Zhao et al. 2011). In women undergoing IVM or IVF, GDNF mRNA levels were significantly increased after $36 \mathrm{~h}$ of hCG treatment (Zhao et al. 2011). These results are consistent with a study by Kawamura et al. (2008), which examined the regulation of Gdnf, 1 Gfra1 and Ret mRNA levels in murine follicles after priming with pregnant mare serum gonadotrophin for $48 \mathrm{~h}$ and again after hCG treatment (Kawamura et al. 2008). Gfra1 mRNA levels increased in cumulus cells and mural granulosa cells in response to hCG but did not change in oocytes. In addition, Ret receptor mRNA levels increased in both cumulus and mural granulosa cells but remained unchanged in oocytes (Kawamura et al. 2008). In further support that gonadotrophins influence the expression of ovarian neurotrophins, Perlman et al. (2006) used oligonucleotide gene chips to evaluate changes in transcript levels in human granulosa cells treated with FSH (Perlman et al. 2006). BDNF was among the differentially expressed genes, with its mRNA levels increasing significantly in response to FSH stimulation (Perlman et al. 2006).

In an ovarian follicle, activin increases the biosynthesis and enhances the actions of $\mathrm{FSH}$, which is directly opposed by the action of inhibin at later states of folliculogenesis. In cultured human fetal ovaries treated with recombinant human activin $\mathrm{A}$, the levels of $B D N F$ mRNA increased significantly compared with untreated controls (Childs et al. 2010). However, there appear to be species differences in the activin A-mediated regulation of $B D N F$ expression in fetal ovarian somatic cells, as no changes in $B d n f$ mRNA levels were reported in cultured cells derived from murine neonatal ovaries (Childs et al. 2010). It was speculated that activin A promotes signals that influence germ cell survival, downregulating those pathways that ultimately lead to oocyte maturation (Childs et al. 2010). Whether BDNF levels are altered by activin in the adult ovary remains to be determined.

\section{Potential clinical significance}

It is clear that GDNF, BDNF and NGF are important ovarian factors that exert a significant influence on both developing and mature follicles. In particular, their roles during oocyte maturation and early development of the embryo make them attractive candidates for inclusion in IVM and IVF treatment regimens that could be of clinical significance. In women undergoing IVF and ICSI, it has been shown that treatment of immature oocytes and granulosa cells with gonadotrophins enhanced the expression of GDNF and BDNF in granulosa cells (Zhao et al. 2011). Furthermore, culturing immature oocytes collected from these patients in the presence 
of GDNF or BDNF revealed that these ovarian neurotrophins promote oocyte maturation in a clinically relevant manner (Zhao et al. 2011). In women with endometriosis receiving assisted reproductive treatment, the follicular fluid concentration of BDNF was lower than in the control group composed of women with male factor infertility, while no differences in NGF concentrations were observed (Buyuk \& Seifer 2008). Interestingly, the levels of NGF in follicular fluid derived from women with polycystic ovary syndrome (PCOS) were lower compared with the control group, but BDNF concentrations did not vary (Buyuk \& Seifer 2008), suggesting an effect potentially attributable to the different aetiologies of infertility. This notion is supported by a recent study demonstrating that follicular fluid BDNF concentrations were only higher in women diagnosed with unexplained infertility following ovulation induction, while no relationship could be established between levels of BDNF or NGF in women with a history of either endometriosis or PCOS compared to controls (Sadeu et al. 2012). It should be noted that this particular study included only a small number of participants, the stage of disease was not factored into the measurements and there may be differences in ovulation induction procedures that vary between facilities that could explain the differences reported across different studies.

As gonadotrophins increase the expression of GDNF, BDNF and NGF in cumulus and granulosa cells (Seifer et al. 2002a, Zhao et al. 2011), and the concentrations of neurotrophins may be lower in the follicular fluid of women with infertility or diagnosed with reproductive disorders after ovarian stimulation, it is possible that the severity of different disease states may alter ovarian function and abrogate the gonadotrophin response of follicular cells through mechanisms that remain to be determined. Therefore, inclusion of these particular neurotrophic factors during IVM/IVF may provide maturing oocytes with sufficient concentrations of neurotrophins that are not available in vivo due to the aetiology of a given reproductive disorder.

From another clinical perspective, while neurotrophins mediate aspects of follicular maturation, it has also become evident that they may play a role in ovarian cancer, mediated through aberrant FSHR expression in ovarian surface epithelium and deregulated secretion of FSH by the pituitary gland (reviewed in Bose (2005)). GDNF may play a role in the aetiology of ovarian cancer, as its expression was initially low in Fshr knockout mice, but in ageing females, which displayed an increase in the incidence of ovarian tumours, GDNF levels were up-regulated (Aravindakshan et al. 2006). By contrast, BDNF is similarly expressed in normal and cancer cell lines and tissues (Au et al. 2009). However, NTRK2 was reported to be overexpressed in ovarian cancers compared to either benign tumours or normal ovarian epithelium (Yu et al. 2008, Au et al. 2009), and its overexpression has been linked with poor prognosis in ovarian cancer patients (Au et al. 2009). It is therefore possible that BDNF/NTRK2-mediated signalling, coupled with crosstalk from other pathways, may be associated with tumour metastasis and chemotherapeutic resistance in ovarian cancer, making NTRK2 a putative therapeutic target (reviewed in Siu et al. (2009)). It has been shown that NGF and NTRK1 are expressed at very low levels in normal ovarian surface epithelium but are significantly more abundant in epithelial ovarian cancer cells (Campos et al. 2007, Tapia et al. 2011). Furthermore, NGF has been shown to dose dependently up-regulate vascular endothelial growth factor (VEGF) isoform expression in cancer explants (Campos et al. 2007), also increasing the proliferation, migration and differentiation of cultured ovarian cancer cells (Tapia et al. 2011), effects that were inhibited by either a NGF antibody or a K252a. These findings were corroborated by Julio-Pieper et al. (2009), who reported that NGF enhances the synthesis and secretion of VEGF from human granulosa cells in an NTRK1-dependent manner (Julio-Pieper et al. 2009).

\section{Future research directions}

Using models from various species, substantial evidence supports the beneficial functional role of GDNF, BDNF and NGF during oocyte maturation and early embryo development. However, substantial knowledge gaps exist, particularly with respect to the mechanisms that drive their effects in COCs upon meiotic resumption, as well as how the expression of these particular neurotrophic factors and their respective receptors is controlled in the postnatal ovary. Identifying the signalling networks regulating the expression of specific neurotrophins will be invaluable, as this could provide a means to intrinsically manipulate their levels in maturing COCs in vitro. Studies aimed at identifying the pathways and genes that are activated in response to neurotrophin stimulation in oocytes, cumulus cells and granulosa cells will provide insights into understanding their regulatory effects at the molecular level. None of these factors act alone, and in order to design a robust IVM regimen, it will be important to systematically dissect how GDNF, BDNF and NGF, in combination with other key ovarian growth factors and hormones, affect ovarian signalling during the final stage of folliculogenesis. In addition, it will be of interest to investigate the role of other neurotrophic factors on oocyte maturation and developmental competence. In particular, NTF3 and NTF4/5 are also expressed in the ovary, may play a role in primordial and primary follicles (Nilsson et al. 2009) and have been implicated in oocyte maturation in women (Seifer et al. $2002 b$ ). Future studies using animal models as a means to monitor the health of offspring generated by IVM/IVF carried out in media containing specific neurotrophins will help to validate their inclusion in assisted reproductive technologies. 


\section{Declaration of interest}

The authors declare that there is no conflict of interest that could be perceived as prejudicing the impartiality of the review.

\section{Funding}

This research was funded by Canada Institutes for Health Research (CIHR), National Science and Research Engineering Council (NSERC), and the EmbryoGENE Strategic Network.

\section{References}

Abir R, Fisch B, Jin S, Barnnet M, Ben-Haroush A, Felz C, KesslerIcekson G, Feldberg D, Nitke S \& Ao A 2005 Presence of NGF and its receptors in ovaries from human fetuses and adults. Molecular Human Reproduction 11 229-236. (doi:10.1093/molehr/gah164)

Anderson RA, Robinson LL, Brooks J \& Spears N 2002 Neurotropins and their receptors are expressed in the human fetal ovary. Journal of Clinical Endocrinology and Metabolism 87 890-897. (doi:10.1210/jc.87.2.890)

Anderson RA, Bayne RA, Gardner J \& De Sousa PA 2010 Brain-derived neurotrophic factor is a regulator of human oocyte maturation and early embryo development. Fertility and Sterility 93 1394-1406. (doi:10.1016/ j.fertnstert.2009.04.007)

Aravindakshan J, Chen XL \& Sairam MR 2006 Age-dependent bimodal GDNF regulation during ovarian tumorigenesis in follitropin receptor mutant mice. Biochemical and Biophysical Research Communications 351 507-513. (doi:10.1016/j.bbrc.2006.10.069)

Au CW, Siu MK, Liao X, Wong ES, Ngan HY, Tam KF, Chan DC, Chan QK \& Cheung AN 2009 Tyrosine kinase B receptor and BDNF expression in ovarian cancers - effect on cell migration, angiogenesis and clinical outcome. Cancer Letters 281 151-161. (doi:10.1016/j.canlet.2009.02.025)

Baloh RH, Enomoto H, Johnson EM Jr \& Milbrandt J 2000 The GDNF family ligands and receptors - implications for neural development. Current Opinion in Neurobiology 10 103-110. (doi:10.1016/S0959-4388 (99)00048-3)

Barboni B, Mattioli M, Gioia L, Turriani M, Capacchietti G, Berardinelli P \& Bernabo N 2002 Preovulatory rise of NGF in ovine follicular fluid: possible involvement in the control of oocyte maturation. Microscopic Research and Technique 59 516-521. (doi:10.1002/jemt.10230)

Begliuomini S, Casarosa E, Pluchino N, Lenzi E, Centofanti M, Freschi L, Pieri M, Genazzani AD, Luisi S \& Genazzani AR 2007 Influence of endogenous and exogenous sex hormones on plasma brain-derived neurotrophic factor. Human Reproduction 22 995-1002. (doi:10.1093/ humrep/del479)

Bibel M \& Barde YA 2000 Neurotrophins: key regulators of cell fate and cell shape in the vertebrate nervous system. Genes and Development $\mathbf{1 4}$ 2919-2937. (doi:10.1101/gad.841400)

Bose CK 2005 Role of nerve growth factor and FSH receptor in epithelial ovarian cancer. Reproductive Biomedicine Online 11 194-197. (doi:10.1016/S1472-6483(10)60958-3)

Buratini J Jr, Teixeira AB, Costa IB, Glapinski VF, Pinto MG, Giometti IC, Barros CM, Cao M, Nicola ES \& Price CA 2005 Expression of fibroblast growth factor- 8 and regulation of cognate receptors, fibroblast growth factor receptor-3c and -4, in bovine antral follicles. Reproduction 130 343-350. (doi:10.1530/rep.1.00642)

Buyuk E \& Seifer DB 2008 Follicular-fluid neurotrophin levels in women undergoing assisted reproductive technology for different etiologies of infertility. Fertility and Sterility 90 1611-1615. (doi:10.1016/j.fertnstert. 2007.08.085)

Campos X, Munoz Y, Selman A, Yazigi R, Moyano L, WeinsteinOppenheimer C, Lara HE \& Romero C 2007 Nerve growth factor and its high-affinity receptor trkA participate in the control of vascular endothelial growth factor expression in epithelial ovarian cancer. Gynecologic Oncology 104 168-175. (doi:10.1016/j.ygyno.2006.07.007)

Cauffman G, Van de Velde H, Liebaers I \& Van Steirteghem A 2005 DAZL expression in human oocytes, preimplantation embryos and embryonic stem cells. Molecular Human Reproduction 11 405-411. (doi:10.1093/ molehr/gah167)
Childs AJ, Bayne RA, Murray AA, Martins Da Silva SJ, Collins CS, Spears N \& Anderson RA 2010 Differential expression and regulation by activin of the neurotrophins BDNF and NT4 during human and mouse ovarian development. Developmental Dynamics 239 1211-1219. (doi:10.1002/ dvdy.22252)

Choi-Lundberg DL \& Bohn MC 1995 Ontogeny and distribution of glial cell line-derived neurotrophic factor (GDNF) mRNA in rat. Brain Research. Developmental Brain Research 85 80-88. (doi:10.1016/01653806(94)00197-8)

Craig J, Orisaka M, Wang H, Orisaka S, Thompson W, Zhu C, Kotsuji F \& Tsang BK 2007 Gonadotropin and intra-ovarian signals regulating follicle development and atresia: the delicate balance between life and death. Frontiers in Bioscience 12 3628-3639. (doi:10.2741/2339)

Cubeddu A, Bucci F, Giannini A, Russo M, Daino D, Russo N, Merlini S, Pluchino N, Valentino V, Casarosa E et al. 2011 Brain-derived neurotrophic factor plasma variation during the different phases of the menstrual cycle in women with premenstrual syndrome. Psychoneuroendocrinology 36 523-530. (doi:10.1016/j.psyneuen.2010.08.006)

Davies AM 2000 Neurotrophins: neurotrophic modulation of neurite growth. Current Biology 10 R198-R200. (doi:10.1016/S09609822(00)00351-1)

Davies AM \& Wright EM 1995 Neurotrophic factors. Neurotrophin autocrine loops. Current Biology 5 723-726. (doi:10.1016/S09609822(95)00144-8)

Dierich A, Sairam MR, Monaco L, Fimia GM, Gansmuller A, LeMeur M \& Sassone-Corsi P 1998 Impairing follicle-stimulating hormone (FSH) signaling in vivo: targeted disruption of the FSH receptor leads to aberrant gametogenesis and hormonal imbalance. PNAS 95 13612-13617. (doi:10.1073/pnas.95.23.13612)

Dissen GA, Hirshfield AN, Malamed S \& Ojeda SR 1995 Expression of neurotrophins and their receptors in the mammalian ovary is developmentally regulated: changes at the time of folliculogenesis. Endocrinology 136 4681-4692. (doi:10.1210/en.136.10.4681)

Dissen GA, Hill DF, Costa ME, Les Dees CW, Lara HE \& Ojeda SR 1996 A role for trkA nerve growth factor receptors in mammalian ovulation. Endocrinology 137 198-209. (doi:10.1210/en.137.1.198)

Dissen GA, Romero C, Paredes A \& Ojeda SR 2002 Neurotrophic control of ovarian development. Microscopic Research and Technique 59 509-515. (doi:10.1002/jemt.10227)

Dissen GA, Garcia-Rudaz C \& Ojeda SR 2009 Role of neurotrophic factors in early ovarian development. Seminars in Reproductive Medicine $\mathbf{2 7}$ 24-31. (doi:10.1055/s-0028-1108007)

Dole G, Nilsson EE \& Skinner MK 2008 Glial-derived neurotrophic factor promotes ovarian primordial follicle development and cell-cell interactions during folliculogenesis. Reproduction 135 671-682. (doi:10.1530/REP-07-0405)

Dong J, Albertini DF, Nishimori K, Kumar TR, Lu N \& Matzuk MM 1996 Growth differentiation factor-9 is required during early ovarian folliculogenesis. Nature 383 531-535. (doi:10.1038/383531a0)

Dorfman MD, Kerr B, Garcia-Rudaz C, Paredes AH, Dissen GA \& Ojeda SR 2011 Neurotrophins acting via TRKB receptors activate the JAGGED1$\mathrm{NOTCH} 2$ cell-cell communication pathway to facilitate early ovarian development. Endocrinology 152 5005-5016. (doi:10.1210/en.20111465)

Elvin JA, Yan C, Wang P, Nishimori K \& Matzuk MM 1999 Molecular characterization of the follicle defects in the growth differentiation factor 9-deficient ovary. Molecular Endocrinology 13 1018-1034. (doi:10.1210/me.13.6.1018)

Farhi J, Ao A, Fisch B, Zhang XY, Garor R \& Abir R 2010 Glial cell linederived neurotrophic factor (GDNF) and its receptors in human ovaries from fetuses, girls, and women. Fertility and Sterility 93 2565-2571. (doi:10.1016/j.fertnstert.2009.09.047)

Fedorushchenko AN, Koval T \& Khamidov D 1996 The effect of a nerve growth factor from different biological sources on the spontaneous maturation of mouse oocytes and on the parthenogenetic activation of pronucleus formation. Tsitologiia 38 1211-1216.

Fedorushchenko AN, Koval T \& Khamidov D 1999 The effect of in-situ nerve growth factor from different biological sources on the reinitiation of mouse oocyte meiotic maturation in culture and on parthenogenetic activation. Ontogenez 30 453-455. 
Feng B, Chen S, Shelden RM \& Seifer DB 2003 Effect of gonadotropins on brain-derived neurotrophic factor secretion by human follicular cumulus cells. Fertility and Sterility $\mathbf{8 0}$ 658-659. (doi:10.1016/S00150282(03)00742-8)

Flood MR, Gage TL \& Bunch TD 1993 Effect of various growth-promoting factors on preimplantation bovine embryo development in vitro. Theriogenology 39 823-833. (doi:10.1016/0093-691X(93)90421-Z)

Golden JP, DeMaro JA, Osborne PA, Milbrandt J \& Johnson EM Jr 1999 Expression of neurturin, GDNF, and GDNF family-receptor mRNA in the developing and mature mouse. Experimental Neurology 158 504-528. (doi:10.1006/exnr.1999.7127)

Hantzopoulos PA, Suri C, Glass DJ, Goldfarb MP \& Yancopoulos GD 1994 The low affinity NGF receptor, p75, can collaborate with each of the Trks to potentiate functional responses to the neurotrophins. Neuron $\mathbf{1 3}$ 187-201. (doi:10.1016/0896-6273(94)90469-3)

Harlow CR, Bradshaw AC, Rae MT, Shearer KD \& Hillier SG 2007 Oestrogen formation and connective tissue growth factor expression in rat granulosa cells. Journal of Endocrinology 192 41-52. (doi:10.1677/ joe.1.06689)

Hong SG, Jang G, Oh HJ, Koo OJ, Park JE, Park HJ, Kang SK \& Lee BC 2009 The effects of brain-derived neurotrophic factor and metformin on in vitro developmental competence of bovine oocytes. Zygote 17 187-193. (doi:10.1017/S0967199409005255)

Jana B, Koszykowska M \& Czarzasta J 2011 Expression of nerve growth factor and its receptors, TrkA and p75, in porcine ovaries. Journal of Reproduction and Development 57 468-474. (doi:10.1262/jrd.10-180H)

Jing S, Wen D, Yu Y, Holst PL, Luo Y, Fang M, Tamir R, Antonio L, Hu Z, Cupples R et al. 1996 GDNF-induced activation of the ret protein tyrosine kinase is mediated by GDNFR- $\alpha$, a novel receptor for GDNF. Cell 85 1113-1124. (doi:10.1016/S0092-8674(00)81311-2)

Julio-Pieper M, Lozada P, Tapia V, Vega M, Miranda C, Vantman D, Ojeda SR \& Romero C 2009 Nerve growth factor induces vascular endothelial growth factor expression in granulosa cells via a trkA receptor/mitogen-activated protein kinase-extracellularly regulated kinase 2-dependent pathway. Journal of Clinical Endocrinology and Metabolism 94 3065-3071. (doi:10.1210/jc.2009-0542)

Kawamura K, Kawamura N, Mulders SM, Sollewijn Gelpke MD \& Hsueh AJ 2005 Ovarian brain-derived neurotrophic factor (BDNF) promotes the development of oocytes into preimplantation embryos. PNAS $\mathbf{1 0 2}$ 9206-9211. (doi:10.1073/pnas.0502442102)

Kawamura K, Ye Y, Kawamura N, Jing L, Groenen P, Gelpke MS, Rauch R, Hsueh AJ \& Tanaka T 2008 Completion of meiosis I of preovulatory oocytes and facilitation of preimplantation embryo development by glial cell line-derived neurotrophic factor. Developmental Biology 315 189-202. (doi:10.1016/j.ydbio.2007.12.029)

Kerr B, Garcia-Rudaz C, Dorfman M, Paredes A \& Ojeda SR 2009 NTRK1 and NTRK2 receptors facilitate follicle assembly and early follicular development in the mouse ovary. Reproduction 138 131-140. (doi:10. 1530/REP-08-0474)

Kezele P, Nilsson E \& Skinner MK 2002 Cell-cell interactions in primordial follicle assembly and development. Frontiers in Bioscience 7 d1990-d1996. (doi:10.2741/kezele)

Klein R, Nanduri V, Jing SA, Lamballe F, Tapley P, Bryant S, CordonCardo C, Jones KR, Reichardt LF \& Barbacid M 1991 The trkB tyrosine protein kinase is a receptor for brain-derived neurotrophic factor and neurotrophin-3. Cell 66 395-403. (doi:10.1016/0092-8674(91)90628-C)

Kohn J, Aloyz RS, Toma JG, Haak-Frendscho M \& Miller FD 1999 Functionally antagonistic interactions between the TrkA and p75 neurotrophin receptors regulate sympathetic neuron growth and target innervation. Journal of Neuroscience 19 5393-5408.

Lara HE, Hill DF, Katz KH \& Ojeda SR 1990 The gene encoding nerve growth factor is expressed in the immature rat ovary: effect of denervation and hormonal treatment. Endocrinology 126 357-363. (doi:10.1210/ endo-126-1-357)

Lara HE, Dees WL, Hiney JK, Dissen GA, Rivier C \& Ojeda SR 1991 Functional recovery of the developing rat ovary after transplantation: contribution of the extrinsic innervation. Endocrinology 129 1849-1860. (doi:10.1210/endo-129-4-1849)

Lee E, Jeong YI, Park SM, Lee JY, Kim JH, Park SW, Hossein MS, Jeong YW, Kim S, Hyun SH et al. 2007 Beneficial effects of brain-derived neurotropic factor on in vitro maturation of porcine oocytes. Reproduction 134 405-414. (doi:10.1530/REP-06-0288)
Lin LF, Doherty DH, Lile JD, Bektesh S \& Collins F 1993 GDNF: a glial cell line-derived neurotrophic factor for midbrain dopaminergic neurons. Science 260 1130-1132. (doi:10.1126/science.8493557)

Linher K, Wu D \& Li J 2007 Glial cell line-derived neurotrophic factor: an intraovarian factor that enhances oocyte developmental competence in vitro. Endocrinology 148 4292-4301. (doi:10.1210/en.2007-0021)

Liu J, Linher K \& Li J 2009 Porcine DAZL messenger RNA: its expression and regulation during oocyte maturation. Molecular and Cellular Endocrinology 311 101-108. (doi:10.1016/j.mce.2009.06.003)

Lommatzsch M, Schloetcke K, Klotz J, Schuhbaeck K, Zingler D, Zingler C, Schulte-Herbruggen O, Gill H, Schuff-Werner P \& Virchow JC 2005 Brain-derived neurotrophic factor in platelets and airflow limitation in asthma. American Journal of Respiratory and Critical Care Medicine $17 \mathbf{1}$ 115-120. (doi:10.1164/rccm.200406-758OC)

Lu B, Pang PT \& Woo NH 2005 The yin and yang of neurotrophin action. Nature Reviews. Neuroscience 6 603-614. (doi:10.1038/nrn1726)

Malamed S, Gibney JA \& Ojeda SR 1992 Ovarian innervation develops before initiation of folliculogenesis in the rat. Cell and Tissue Research 270 87-93. (doi:10.1007/BF00381883)

Martins da Silva SJ, Gardner JO, Taylor JE, Springbett A, De Sousa PA \& Anderson RA 2005 Brain-derived neurotrophic factor promotes bovine oocyte cytoplasmic competence for embryo development. Reproduction 129 423-434. (doi:10.1530/rep.1.00471)

McElroy SL, Byrne JA, Chavez SL, Behr B, Hsueh AJ, Westphal LM \& Pera RA 2010 Parthenogenic blastocysts derived from cumulus-free in vitro matured human oocytes. PLoS ONE 5 e10979. (doi:10.1371/ journal.pone.0010979)

Monteleone P, Artini PG, Simi G, Cela V, Casarosa E, Begliuomini S, Ninni F, Pluchino N, Luisi M \& Genazzani AR 2007 Brain derived neurotrophic factor circulating levels in patients undergoing IVF. Journal of Assisted Reproduction and Genetics $24 \quad 477-480$. (doi:10.1007/s10815-007-9169-y)

Nebreda AR, Martin-Zanca D, Kaplan DR, Parada LF \& Santos E 1991 Induction by NGF of meiotic maturation of Xenopus oocytes expressing the trk proto-oncogene product. Science 252 558-561. (doi:10.1126/ science.1850550)

Nilsson E, Dole G \& Skinner MK 2009 Neurotrophin NT3 promotes ovarian primordial to primary follicle transition. Reproduction 138 697-707. (doi:10.1530/REP-09-0179)

Ojeda SR, Romero C, Tapia V \& Dissen GA 2000 Neurotrophic and cellcell dependent control of early follicular development. Molecular and Cellular Endocrinology 163 67-71. (doi:10.1016/S0303-7207(99) 00242-7)

Papp AB, Somfai T, Tartaglione M, Varga E \& Gardon JC 2005 The effect of nerve growth factor on nuclear progression of porcine oocytes during in vitro maturation and embryo development. Acta Veterinaria Hungarica 53 91-101. (doi:10.1556/AVet.53.2005.1.9)

Paredes A, Romero C, Dissen GA, DeChiara TM, Reichardt L, Cornea A, Ojeda SR \& Xu B 2004 TrkB receptors are required for follicular growth and oocyte survival in the mammalian ovary. Developmental Biology 267 430-449. (doi:10.1016/j.ydbio.2003.12.001)

Perlman S, Bouquin T, van den Hazel B, Jensen TH, Schambye HT, Knudsen S \& Okkels JS 2006 Transcriptome analysis of FSH and FSH variant stimulation in granulosa cells from IVM patients reveals novel regulated genes. Molecular Human Reproduction 12 135-144. (doi:10.1093/molehr/gah247)

Pluchino N, Cubeddu A, Begliuomini S, Merlini S, Giannini A, Bucci F, Casarosa E, Luisi M, Cela V \& Genazzani AR 2009 Daily variation of brain-derived neurotrophic factor and cortisol in women with normal menstrual cycles, undergoing oral contraception and in postmenopause. Human Reproduction 24 2303-2309. (doi:10.1093/humrep/dep119)

Raffioni S, Bradshaw RA \& Buxser SE 1993 The receptors for nerve growth factor and other neurotrophins. Annual Review of Biochemistry 62 823-850. (doi:10.1146/annurev.bi.62.070193.004135)

Reynolds N, Collier B, Bingham V, Gray NK \& Cooke HJ 2007 Translation of the synaptonemal complex component Sycp3 is enhanced in vivo by the germ cell specific regulator Dazl. RNA 13 974-981. (doi:10.1261/rna. 465507)

Romero C, Paredes A, Dissen GA \& Ojeda SR 2002 Nerve growth factor induces the expression of functional FSH receptors in newly formed follicles of the rat ovary. Endocrinology 143 1485-1494. (doi:10.1210/ en.143.4.1485) 
Sadeu JC, Doedee AM, Neal MS, Hughes EG \& Foster WG 2012 Neurotrophins (BDNF and NGF) in follicular fluid of women with different infertility diagnoses. Reproductive Biomedicine Online $\mathbf{2 4}$ 174-179. (doi:10.1016/j.rbmo.2011.11.011)

Salas C, Julio-Pieper M, Valladares M, Pommer R, Vega M, Mastronardi C, Kerr B, Ojeda SR, Lara HE \& Romero C 2006 Nerve growth factordependent activation of trkA receptors in the human ovary results in synthesis of follicle-stimulating hormone receptors and estrogen secretion. Journal of Clinical Endocrinology and Metabolism 91 2396-2403. (doi:10.1210/jc.2005-1925)

Sariola H \& Saarma M 2003 Novel functions and signalling pathways for GDNF. Journal of Cell Science 116 3855-3862. (doi:10.1242/jcs.00786)

Sehgal A, Wall DA \& Chao MV 1988 Efficient processing and expression of human nerve growth factor receptors in Xenopus laevis oocytes: effects on maturation. Molecular and Cellular Biology 8 2242-2246. (doi:10.1128/MCB.8.5.2242)

Seifer DB, Feng B, Shelden RM, Chen S \& Dreyfus CF 2002a Brain-derived neurotrophic factor: a novel human ovarian follicular protein. Journal of Clinical Endocrinology and Metabolism 87 655-659. (doi:10.1210/jc. 87.2.655)

Seifer DB, Feng B, Shelden RM, Chen S \& Dreyfus CF $2002 b$ Neurotrophin$4 / 5$ and neurotrophin- 3 are present within the human ovarian follicle but appear to have different paracrine/autocrine functions. Journal of Clinical Endocrinology and Metabolism 87 4569-4571. (doi:10.1210/jc.2002020499)

Seifer DB, Lambert-Messerlian G \& Schneyer AL 2003 Ovarian brainderived neurotrophic factor is present in follicular fluid from normally cycling women. Fertility and Sterility 79 451-452. (doi:10.1016/S00150282(02)04669-1)

Shi Z, Jin W, Watanabe G, Suzuki AK, Takahashi S \& Taya K 2004 Expression of nerve growth factor (NGF), and its receptors trkA and p75 in ovaries of the cyclic golden hamster (Mesocricetus auratus) and the regulation of their production by luteinizing hormone. Journal of Reproduction and Development 50 605-611. (doi:10.1262/jrd.50.605)

Shi Z, Arai KY, Jin W, Weng Q, Watanabe G, Suzuki AK \& Taya K 2006 Expression of nerve growth factor and its receptors NTRK1 and TNFRSF1B is regulated by estrogen and progesterone in the uteri of golden hamsters. Biology of Reproduction 74 850-856. (doi:10.1095/ biolreprod.105.044917)

Siu MK, Wong OG \& Cheung AN 2009 TrkB as a therapeutic target for ovarian cancer. Expert Opinion on Therapeutic Targets 13 1169-1178. (doi:10.1517/14728220903196787)

Skinner MK 2005 Regulation of primordial follicle assembly and development. Human Reproduction Update 11 461-471. (doi:10.1093/ humupd/dmi020)

Snider WD 1994 Functions of the neurotrophins during nervous system development: what the knockouts are teaching us. Cell 77 627-638. (doi:10.1016/0092-8674(94)90048-5)

Takahashi M 2001 The GDNF/RET signaling pathway and human diseases. Cytokine \& Growth Factor Reviews 12 361-373. (doi:10.1016/S1359. 6101(01)00012-0)

Tapia V, Gabler F, Munoz M, Yazigi R, Paredes A, Selman A, Vega M \& Romero C 2011 Tyrosine kinase A receptor (trkA): a potential marker in epithelial ovarian cancer. Gynecologic Oncology 121 13-23. (doi:10.1016/j.ygyno.2010.12.341)
Tomac A, Lindqvist E, Lin LF, Ogren SO, Young D, Hoffer BJ \& Olson L 1995 Protection and repair of the nigrostriatal dopaminergic system by GDNF in vivo. Nature 373 335-339. (doi:10.1038/373335a0)

Toran-Allerand CD 1996a The estrogen/neurotrophin connection during neural development: is co-localization of estrogen receptors with the neurotrophins and their receptors biologically relevant? Developmental Neuroscience 18 36-48. (doi:10.1159/000111393)

Toran-Allerand CD 1996b Mechanisms of estrogen action during neural development: mediation by interactions with the neurotrophins and their receptors? Journal of Steroid Biochemistry and Molecular Biology 56 169-178. (doi:10.1016/0960-0760(95)00234-0)

Treanor JJ, Goodman L, de Sauvage F, Stone DM, Poulsen KT, Beck CD, Gray C, Armanini MP, Pollock RA, Hefti F et al. 1996 Characterization of a multicomponent receptor for GDNF. Nature 382 80-83. (doi:10.1038/ 382080a0)

Trupp M, Ryden M, Jornvall H, Funakoshi H, Timmusk T, Arenas E \& Ibanez CF 1995 Peripheral expression and biological activities of GDNF, a new neurotrophic factor for avian and mammalian peripheral neurons. Journal of Cell Biology 130 137-148. (doi:10.1083/jcb.130.1.137)

Valve E, Penttila TL, Paranko J \& Harkonen P 1997 FGF-8 is expressed during specific phases of rodent oocyte and spermatogonium development. Biochemical and Biophysical Research Communications 232 173-177. (doi:10.1006/bbrc.1997.6256)

Weng Q, Shi Z, Tukada J, Watanabe G \& Taya K 2009 Immunodetection of NGF, trkA, p75 and inhibin $\alpha$-subunit in interstitial cells of golden hamsters treated with hCG. Journal of Reproduction and Development 55 622-628. (doi:10.1262/jrd.20208)

Widenfalk J, Parvinen M, Lindqvist E \& Olson L 2000 Neurturin, RET, GFR $\alpha-1$ and GFR $\alpha-2$, but not GFR $\alpha-3$, mRNA are expressed in mice gonads. Cell and Tissue Research 299 409-415. (doi:10.1007/ s004419900068)

Yu X, Liu L, Cai B, He Y \& Wan X 2008 Suppression of anoikis by the neurotrophic receptor TrkB in human ovarian cancer. Cancer Science $\mathbf{9 9}$ 543-552. (doi:10.1111/j.1349-7006.2007.00722.x)

Zhang L, Li J, Su P \& Xiong C 2010a The role of brain-derived neurotrophic factor in mouse oocyte maturation in vitro. Journal of Huazhong University of Science and Technology. Medical Sciences 30 781-785. (doi:10.1007/s11596-010-0658-3)

Zhang L, Liang Y, Liu Y \& Xiong CL $2010 b$ The role of brain-derived neurotrophic factor in mouse oocyte maturation in vitro involves activation of protein kinase B. Theriogenology 73 1096-1103. (doi:10.1016/j. theriogenology.2010.01.009)

Zhao P, Qiao J, Huang S, Zhang Y, Liu S, Yan LY, Hsueh AJ \& Duan EK 2011 Gonadotrophin-induced paracrine regulation of human oocyte maturation by BDNF and GDNF secreted by granulosa cells. Human Reproduction 26 695-702. (doi:10.1093/humrep/deq390)

Received 14 June 2012

First decision 22 August 2012

Revised manuscript received 8 November 2012

Accepted 19 November 2012 